\title{
KARAKTERISTIK EDIBLE FILM DARI EKSTRAK KACANG KEDELAI DENGAN PENAMBAHAN TEPUNG TAPIOKA DAN GLISEROL SEBAGAI BAHAN PENGEMAS MAKANAN
}

\author{
Loisa Lorensia Sinaga, Melisa Seri Rejekina S, Mersi Suriani Sinaga \\ Departemen Teknik Kimia, Fakultas Teknik Universitas Sumatera Utara \\ Jl. Almamater Kampus USU Medan, 20155 Indonesia \\ lorensia_cinaga@yahoo.com
}

\begin{abstract}
Abstrak
Salah satu cara untuk mengatasi lingkungan dalam penggunaan plastik nonbiodegradable adalah dengan memakai pengemas biodegradable. Edible film merupakan lapisan tipis yang digunakan untuk melapisi makanan. Pada penelitian ini, edible film dibuat dari campuran ekstrak kacang kedelai dengan pati dan gliserol. Pengolahan edible film diawali dengan pembuatan ekstrak protein kacang kedelai atau pembuatan susu kedelai. Susu kedelai ditambahkan dengan tepung tapioka dan variasi gliserol 2; 4; 6; 8 dan 10 $(\mathrm{ml} / 100 \mathrm{ml}$ susu kedelai). Kemudian campuran diaduk menggunakan magnetic stirer, dicetak dan dikeringkan di oven pada suhu $40{ }^{\circ} \mathrm{C} \pm 2$ hari. Setelah itu dilakukan uji karakteristik edible film, meliputi ketebalan, kekuatan tarik dan pemanjangan saat pemutusan. Hasil penelitian menunjukkan penambahan gliserol berpengaruh terhadap ketebalan edible film, kekuatan tarik dan pemanjangan saat pemutusan. Adapun ketebalan yang diperoleh meningkat seiring penambahan gliserol, yaitu 0,208 mm;0,228 mm; $0,248 \mathrm{~mm} ; 0,274 \mathrm{~mm}$ dan 0,294 $\mathrm{mm}$. Kekuatan tarik yang diperoleh menurun dengan peningkatan ketebalan edible film, yaitu 0,105 MPa; 0,134 MPa; 0,088 MPa; 0,072 MPa dan 0,048 MPa. Pemanjangan saat pemutusan yang diperoleh meningkat dengan peningkatan ketebalan edible film, yaitu 1,839\%; 3,270\%; 3,842\%; 5,779\% dan 6,158\%. Dari uji karakteristik yang dilakukan diperoleh yang terbaik pada ketebalan edible film $0,228 \mathrm{~mm}$.
\end{abstract}

Kata kunci : edible film, gliserol, ketebalan, kekuatan tarik, dan pemanjangan saat pemutusan

\begin{abstract}
One way to solve the environment issue in the usage of nonbiodegradable plastic is by using biodegradable packaging. Edible film is a thin layer which is overlay the food. In this research, edible film made from mixture of soybean extract with starch and glycerol. The process of making edible films is began with producing soybean protein extract producing soy milk. Soy milk added by tapioca flour and glyserol variations : $2 ; 4 ; 6 ; 8$ and $10(\mathrm{ml} / 100 \mathrm{ml}$ soy milk). Then, the mixture stirred by using magnetic stirer, formed and dried in the oven at the temperature of $40{ }^{\circ} \mathrm{C} \pm 2$ days. After that, the characteristics test of edible film done by checking the thickness, the tensile strength and elongation at break. The results of research shows that the addition of glycerol influence the edible film's thickness, tensile strength and elongation at break. The thickness obtained from the increasing of the addition glycerol. They are 0,208 $\mathrm{mm} ; 0,228 \mathrm{~mm} ; 0,248 \mathrm{~mm} ; 0,274 \mathrm{~mm}$ and $0,294 \mathrm{~mm}$. The tensile strength will decrease if the thickness of the edible film increase. They are 0,105 MPa; 0,134 MPa; 0,088 MPa; 0,072 MPa and 0,048 MPa. The elongation at break which is obtained will increase by increasing of edible film's thickness. They are 1,839\%; 3,270\%; 3,842\%; 5,779\%, and 6,158\%. The characteristic's test shows that the best thickness of edible film is $0,228 \mathrm{~mm}$.
\end{abstract}

Keywords: edible film, glycerol, thickness, tensile strength, and elongation at break

\section{Pendahuluan}

Plastik merupakan suatu benda yang tidak dapat dilepaskan dari kehidupan masyarakat seharihari. Sampah plastik tergolong dalam sampah non organik yang sangat berbahaya bagi lingkungan karena membutuhkan waktu dan proses yang lama yaitu 1.000 tahun untuk dapat diuraikan secara alami di tanah dan 450 tahun untuk terurai di air. Penggunaan plastik ini banyak digunakan untuk kemasan pada bahan pangan dan masih bersifat nonbiodegradable [1].

Salah satu cara untuk mengatasi masalah tersebut adalah dengan memakai pengemas makanan yang biodegradable. Pengemas biodegradable ini dibuat dari bahan alami, seperti kacang kedelai, singkong, dan sebagainya. Pengemas biodegradable ini termasuk ke dalam edible film karena berdasarkan sifat mekaniknya dapat menggantikan plastik nonbiodegradable.

Edible film merupakan lapisan tipis yang digunakan untuk melapisi makanan, atau diletakkan di antara komponen yang berfungsi sebagai penahan terhadap transfer massa seperti air, oksigen, dan lemak. Edible film dapat bergabung dengan bahan tambahan makanan untuk mempertinggi kualitas warna, aroma, dan tekstur produk, serta untuk mengontrol pertumbuhan mikroba [6]. 
Penggunaan edible film untuk pengemasan produk-produk pangan seperti sosis, buah-buahan dan sayuran segar dapat memperlambat penurunan mutu, karena edible film dapat berfungsi sebagai penahan difusi gas oksigen, karbondioksida dan uap air serta komponen flavor, sehingga mampu menciptakan kondisi atmosfir internal yang sesuai dengan kebutuhan produk yang dikemas [6].

Kedelai (Glycine max) merupakan salah satu komoditas hasil pertanian tanaman pangan berprotein tinggi yang sudah meluas penggunaannya di masyarakat. Kedelai mengandung protein $35 \%$ bahkan varietas unggul kadar proteinya dapat mencapai 40-43\%. Kandungan protein kedelai lebih tinggi dari jenis kacang-kacangan lainnya [7]. Secara lengkap kandungan gizi kacang kedelai dapat dilihat pada tabel 1.

Tabel 1. Kandungan Gizi Kacang Kedelai [7]

\begin{tabular}{|l|c|}
\hline \multicolumn{1}{|c|}{ Kandungan Gizi } & $\begin{array}{c}\text { Kacang } \\
\text { Kedelai }\end{array}$ \\
\hline Air (\%) & 8 \\
\hline Energi (kal) & 331 \\
\hline Protein (\%) & 34,9 \\
\hline Lemak (\%) & 18,1 \\
\hline Karbohidrat (\%) & 35 \\
\hline Ca (mg/100 gr) & 227 \\
\hline Fe (mg/100 gr) & 8,0 \\
\hline Beta karotin equivalent (mcg) & 10 \\
\hline Thiamin (mg/100 gr) & 1,07 \\
\hline Riboflavin (mg/100 gr) & 0,30 \\
\hline Niacin (mg/100 gr) & 2,0 \\
\hline Vitamin C (mg/100 gr) & 8 \\
\hline
\end{tabular}

Polisakarida seperti pati dapat dijadikan sebagai bahan baku pada pembuatan edible film. Pati sering digunakan dalam industri pangan sebagai biodegradable film untuk menggantikan polimer plastik karena ekonomis, dapat diperbaharui dan memberikan karakteristik fisik yang baik [3]. Tapioka sering digunakan sebagai bahan tambahan atau pengisi karena kandungan patinya yang cukup tinggi [5]

Gliserol merupakan plasticizer yang bersifat hidrofilik, sehingga cocok untuk bahan pembentukan film yang bersifat hidrofobik seperti pati. Ia dapat meningkatkan penyerapan molekul polar seperti air. Peran gliserol sebagai plasticizer dan konsentrasinya meningkatkan fleksibilitas film. Gliserol (gliserin) merupakan senyawa poliol sederhana. Ini adalah tidak berwarna, tidak berbau, cairan kental yang banyak digunakan dalam formulasi farmasi [2].

Beberapa penelitian sebelumnya menunjukkan bahwa penambahan tapioka berpengaruh pada sifat fisik edible film. Evi Suliastini menyimpulkan bahwa penambahan tapioka pada pembuatan edible film dari ekstrak wortel meningkatakan sifat keelastisan dan tidak rapuh untuk dimanfaatkan sebagai bahan pengemas makanan [11]. Pembuatan edible film dari ekstraksi pektin cincau hijau dengan penambahan tapioka juga dipelajari oleh Arinda Rachmawati [9].

\section{Metodologi Penelitian}

Bahan baku yang digunakan dalam penelitian ini adalah kacang kedelai, tepung tapioka, dan gliserol, sedangkan peralatan utama yang digunakan adalah blender, magnetic stirer, hot plate, oven listrik, timbangan, dan cetakan. Percobaan ini dilakukan dengan variasi konsentrasi gliserol $2 \%, 4 \%, 6 \%, 8 \%$, dan $10 \%$.

Bahan baku kacang kedelai mula-mula dipilih, ditimbang sebanyak 75 gr dan dicuci. Kemudian direndam dengan menggunakan air mendidih selama 60 detik. Kacang kedelai dipisahkan dan ditambahkan air panas $90^{\circ} \mathrm{C}$ sebanyak $450 \mathrm{ml}$ dan diblender. Bubur kacang kedelai dimasak dengan suhu 95-98 ${ }^{\circ} \mathrm{C}$ selama 10 menit, disaring dan diperoleh susu kedelai. Kemudian tepung tapioka 10 gr ditambahkan ke dalam susu kedelai $100 \mathrm{ml}$. Campuran dipanaskan di atas hot plate dan diaduk dengan stirer sampai suhu $60{ }^{\circ} \mathrm{C}$. Kemudian ditambahkan gliserol dengan variasi $2 \%, 4 \%, 6 \%$, $8 \%$, dan $10 \%$. Diaduk sampai suhu $65-70{ }^{\circ} \mathrm{C}$. Kemudian larutan dituang ke dalam cetakan kaca akrilik 20 x $20 \mathrm{~cm}$. Lalu dikeringkan di dalam oven \pm 24 jam suhu $40{ }^{\circ} \mathrm{C}$. Edible film yang terbentuk diukur ketebalannya dengan menggunakan mikrometer digital mitutoyo dengan diukur pada 5 titik yang berbeda dan diambil rata-ratanya. Uji kekuatan tarik dan pemanjangan saat pemutusan menggunakan torsee's electronic system universal testing machine yang dicetak 3 setiap sampel dan diambil rata-ratanya. Pada penelitian ini juga dilakukan pengujian FTIR (Fourier Transformed Infra Red) terhadap Edible film terbaik yang dihasilkan.

\section{Hasil dan Pembahasan}

\section{Ketebalan Edible Film}

Pengaruh penambahan gliserol terhadap ketebalan edible film dapat dilihat pada gambar 1 .

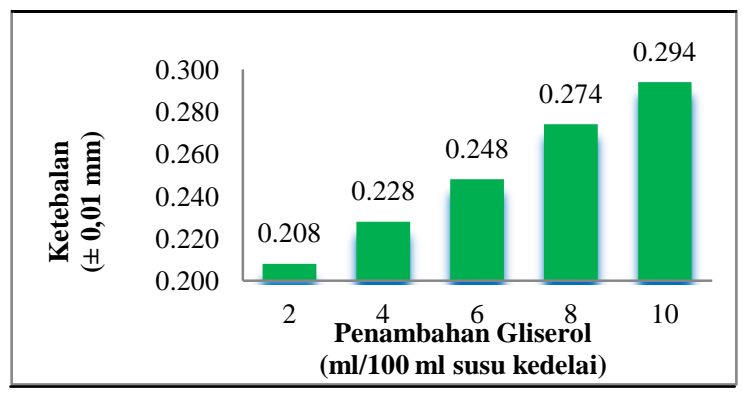

Gambar 1. Pengaruh Penambahan Gliserol Terhadap Ketebalan Edible Film 
Ketebalan merupakan parameter penting yang berpengaruh terhadap penggunaan film dalam pembentukan produk yang akan dikemasnya. Ketebalan dapat mempengaruhi laju trnsmisi uap, gas, dan senyawa volatil serta sifat fisik lainnya seperti kekuatan tarik dan pemanjangan pada saat putus edible film yang dihasilkan.

Dari gambar 1 dapat dilihat bahwa penambahan gliserol berbanding lurus dengan ketebalan film yang diperoleh. Ketebalan edible film yang dihasilkan meningkat dengan penambahan gliserol. Dengan jumlah protein yang relatif sama dalam tiap jenis film, maka makin tinggi penambahan gliserol makin tinggi pula kandungan film sehingga makin tebal film yang dihasilkan, demikian juga sebaliknya makin sedikit penambahan gliserol makin rendah pula kandungan film sehingga makin tipis film yang dihasilkan [13].

Menurut Poeloengsih melaporkan hasil penelitian edible film yang dibuat komposit protein biji kecipir 2,5\% (b/v), tapioka $1 \%(\mathrm{~b} / \mathrm{v})$, sorbitol $1 \%$ (b/v) dan variasi asam palmitat $0 \%-8 \%$ memiliki ketebalan $0,096 \mathrm{~mm}-0,104 \mathrm{~mm}$. Sedangkan menurut Yoyo melaporkan hasil penelitian edible film yang dibuat dari kacang kedelai dengan variasi gliserol 4\%-10\% dan tanpa penambahan tapioka memiliki ketebalan 0,1730 $\mathrm{mm}$ - 0,2943 mm. Perbedaan ketebalan antara berbagai jenis film tersebut disebabkan komposisi formula film yang berbeda.

\section{Kekuatan Tarik}

Pengaruh Kekuatan Tarik (Tensile Strength) terhadap Ketebalan Edible Film dapat dilihat pada gambar 2.

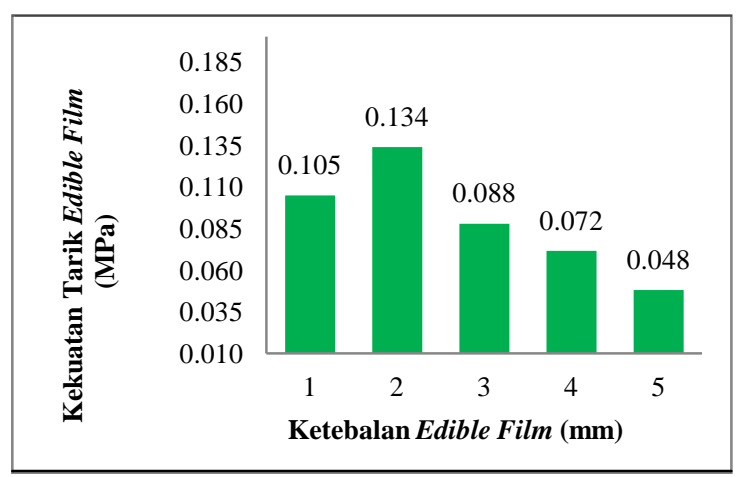

Gambar 2. Pengaruh Kekuatan Tarik (Tensile Strength) terhadap Ketebalan Edible Film

Kekuatan tarik pada penelitian ini diuji dengan menggunakan Torsee's Electronic System Universal Testing Machine dengan kecepatan 20 $\mathrm{mm} / \mathrm{menit}$ dan beban $100 \mathrm{kgf}$. Sebelum diuji sampel terlebih dahulu dicetak dengan menggunakan ASTM D-882. Setiap sampel dicetak sebanyak 3 dan diambil rata-rata dari pengujian tersebut.

Dari gambar 2 secara keseluruhan dapat dilihat bahwa kekuatan tarik berbanding terbalik dengan ketebalan edible film yang dihasilkan. Kekuatan tarik menurun dengan meningkatnya ketebalan dari edible film. Pada ketebalan 0,228 $\mathrm{mm}$ diperoleh kekuatan tarik 0,105 $\mathrm{MPa}$, sedangkan pada ketebalan 0,228 $\mathrm{mm}$ diperoleh kekuatan tarik 0,134 MPa. Kekuatan tarik menurun terus pada ketebalan 0,248 $\mathrm{mm} ; 0,274 \mathrm{~mm}$; dan 0,294 mm dengan kekuatan tarik 0,088 $\mathrm{MPa} ; 0,072$ $\mathrm{MPa}$; dan 0,048 MPa.

Kekuatan tarik akan menurun disebabkan oleh reduksi interaksi intermolekuler rantai protein sehingga matriks film yang terbentuk akan semakin sedikit. Reduksi interaksi intermolekuler rantai protein terjadi disebabkan oleh penambahan gliserol, molekul plasticizer akan menganggu kekompakan pati, menurunkan interaksi intermolekul dan meningkatkan mobilitas polimer [10].

Penambahan gliserol akan meningkatkan ketebalan edible film yang dihasilkan sehingga dengan semakin bertambahnya ketebalan edible film yang dihasilkan akan menurunkan kekuatan tarik edible film. Hal ini menunjukkan bahwa kekuatan tarik dari edible film yang dihasilkan berbanding terbalik dengan ketebalan.

\section{Pemanjangan saat Pemutusan Edible Film}

Pengaruh Penambahan Gliserol Terhadap Pemanjangan saat Pemutusan (Elongation at Break) Edible Film dapat dilihat pada gambar 3.

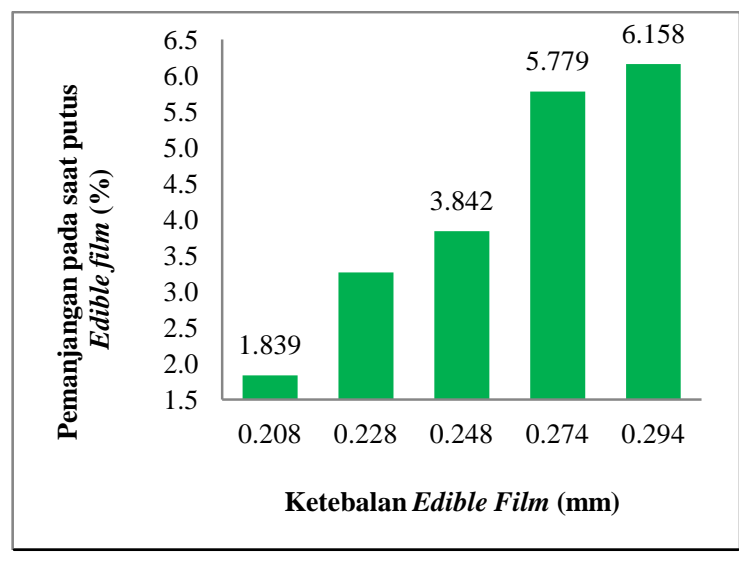

Gambar 3. Pengaruh Penambahan Gliserol Terhadap Pemanjangan saat Pemutusan (Elongation at Break) Edible Film

Pemanjangan pada saat putus menunjukkan perubahan panjang film maksimum saat memperoleh gaya tarik sampai film putus dibandingkan dengan panjang awalnya. 
Dari gambar 3 menunjukkan bahwa ketebalan film berbanding lurus dengan pemanjangan saat pemutusan edible film. Pemanjangan pada saat putus yang dihasilkan semakin meningkat dengan meningkatnya ketebalan. Pada ketebalan 0,208 mm diperoleh pemanjangan pada saat putus $1,839 \%$, sedangkan pada ketebalan 0,228 mm diperoleh pemanjangan pada saat putus 3,270\%. Pemanjangan pada saat putus terus meningkat seiring pada meningkatnya ketebalan $0,248 \mathrm{~mm}$; $0,274 \mathrm{~mm}$ dan $0,294 \mathrm{~mm}$ yaitu $3,842 \% ; 5,779 \%$ dan $6,158 \%$.

Berdasarkan uraian di atas bahwa ketebalan edible film juga mempengaruhi pemanjangan pada saat putus yang dihasilkan. Reduksi interaksi intermolekuler rantai protein terjadi disebabkan oleh penambahan gliserol, molekul plasticizer akan mengganggu kekompakan pati, menurunkan interaksi intermolekul dan meningkatkan mobilitas polimer. Selanjutnya menyebabkan peningkatan pemanjangan pada saat putus seiring dengan peningkatan konsentrasi gliserol [10].

Penambahan gliserol akan meningkatkan ketebalan edible film yang dihasilkan sehingga dengan semakin bertambahnya ketebalan edible film yang dihasilkan akan meningkatkan pemanjangan pada saat putus edible film. Hal ini menunjukkan bahwa pemanjangan pada saat putus dari edible film yang dihasilkan berbanding lurus dengan ketebalan.

\section{Gugus Fungsi Kacang Kedelai}

Gugus fungsi Kacang Kedelai dapat dilihat pada gambar 4.

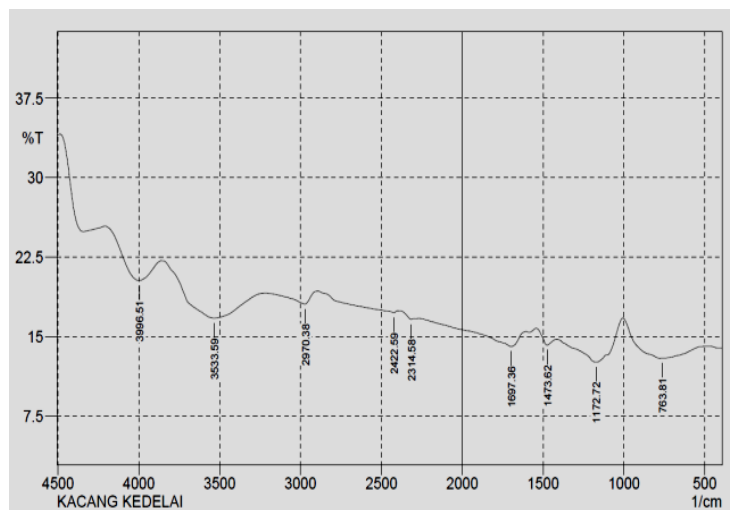

Gambar 4. Analisa FTIR Edible Film Kacang Kedelai

Hasil FTIR (Fourier Transformed Infra Red) edible film dari ekstrak kacang kedelai dengan penambahan kacang kedelai dan gliserol menunjukkan gugus fungsi yang terkandung pada edible film yang dihasilkan. Gabungan ikatan ikatan $\mathrm{O}-\mathrm{H}$ dengan ikatan intermolekul $\mathrm{H}$ dan ikatan intramolekul N-H ditunjukkan pada puncak
$3533,59 \mathrm{~cm}^{-1}$. Sedangkan ikatan $\mathrm{C}-\mathrm{H}$ yang secara umum merupakan karakteristik grup aldehid ditunjukkan pada penyerapan $2970,38 \mathrm{~cm}^{-1}$. Ikatan $\mathrm{C}=\mathrm{O}$, ikatan $\mathrm{N}-\mathrm{H}$ pada fase padat, dan ikatan karbonil C-O ditunjukkan pada penyerapan $1697,36 \mathrm{~cm}^{-1}, 1473,62 \mathrm{~cm}^{-1}$, dan $1172,72 \mathrm{~cm}^{-1}$ [4].

\section{Kesimpulan}

Berdasarkan hasil penelitian dapat disimpulkan bahwa penambahan tepung tapioka dan variasi gliserol mempengaruhi karakteristik dari edible film. Peningkatan penambahan gliserol dapat meningkatkan ketebalan edible film dan pemanjangan saat pemutusan edible film. Berbeda dengan kekuatan tarik yang menurun dengan peningkatan penambahan gliserol. Dari hasil penelitian diperoleh edible film yang terbaik adalah pada penambahan gliserol $4 \mathrm{ml} / 100 \mathrm{ml}$ susu kedelai. Ketebalan, kekuatan tarik, dan pemanjangan saat pemutusan yang diperoleh adalah $0,228 \mathrm{~mm} ; 0,134$ Mpa; dan 3,270\%.

\section{Daftar Pustaka}

[1] Adiwijaya, Michael, Peran Pemerintah, Industri Ritel, dan Masyarakat dalam Membatasi Penggunaan Kantong Plastik Sebagai Salah Satu Upaya Pelestarian Lingkungan, Skripsi, Fakultas Ekonomi Universitas Kristen Petra, 2009.

[2] Austin, T, Shenrve's Chemistry Process Industries, Fourth Edition, New York: McGraw Hill Book Company, 1985.

[3] Bourtoon, T, Effect of Some Process parameters on The Properties of Edible Film Prepared From Starch, Department of Material Product Technology, Songkhala, 2007.

[4] Emad, dkk, Preparation and Characterization of Soy protein Based Edible/Biodegradable Films, American Journal of Food Technology 2007, p 462-476.

[5] Hui, Y H, Handbook of Food Science, Technology, and Engineering, Volume I, USA: CRC Press, 2006.

[6] Krochta and De Mulder Johnston, Edible and Biodegradable Polymer Film: Changes \& Opportunities, Food Technology 51, 1997.

[7] Layuk, P M Lintang, G H Yoseph, M M Rumoki, R Novarianto, dan J G Kindangen, Pasca Panen dan Pengolahan Kedelai, Balai pengkajian Teknologi pertanian Sulawesi Utara, 2002.

[8] Poeloengasih, C D Karakteristik Edible Film komposit Protein Biji kecipir (Psophocarpus tetregonolobus (L) DC) dan Tapioka, Tesis, Program pascasarjana Jurusan Ilmu dan Teknologi Pangan UGM, Yogyakarta, 2003. 
[9] Rachmawati, A Ekstraksi dan Karakterisasi Cincau Hijau untuk Pembuatan Edible Film, Skripsi, Fakultas Pertanian Universitas Sebelas Maret, Surakarta, 2009.

[10] Rodrigues, M J Ose's, K Ziani dan J I Mate, Conbined effect of plasticizer and surfactans on the physical properties of Strach based ediblw films, Food Research International, 2006, p 840-846.

[11] Suliastini, E, Pembuatan Edible Film dari Campuran Kanji, Ekstrak Pepaya dan Gliserin sebagai Bahan Pengemas, Skripsi, Departemen Kimia Universitas Sumatera Utara, Medan, 2011.

[12] Suprapto, Bertanam Kedelai, Penebar Swadaya, Jakarta, 1997.

[13] Yoyo, T, Mempelajari Karakteristik Fisik Edible Film Dari Protein Kedela, Skripsi, Fakultas Teknologi Pertanian Institut Pertanian Bogor, Bogor, 1995. 